\title{
Spatial pattern in the abundance and structure of mollusc populations in the soft sediments of a coral reef lagoon
}

\author{
G. P. Jones ${ }^{\bullet}$, D. J. Ferrell ${ }^{*}$, P. F. Sale ${ }^{\cdots}$ \\ School of Biological Sciences, University of Sydney, Sydney, 2006 NSW, Australia
}

\begin{abstract}
A hierarchical sampling programme, carried out during October 1985, encompassed 4 spatial scales: broad habitat zones of different depth and sediment composition; random 1 ha locations within zones; random $25 \mathrm{~m}^{2}$ sites within locations; and random $0.01 \mathrm{~m}^{2}$ air-lifted cores from each site. Of 69 species collected, we describe the patterns of distribution of the 10 most common. Spatial differences in their abundances were observed at all scales, but most of the variation (50 to $85 \%$ ) occurred at the broadest scale - between zones. Zones of peak abundance differed among species, some being most abundant in deep, fine-sediment habitats, e.g. Tellina cf. myaformis; some in deep, intermediatesediment habitats, e.g. Exotica cf. virgulata and Pupa nitidula; others in shallow, coarse-sediments to the north, e.g. Tellina obtusalis, Umbonium guamensis; and still others in the shallow sediments to the south, e.g. Rhinoclavis aspera. In terms of population structure, tellinid bivalves reached greatest sizes in the coarse shallow zones. At the broadest scale, zones did not appear to represent homogeneous assemblages, due largely to a variable response of species to the environment at a location scale. Overall, species richness tended to increase from fine to coarse sediment, except at the very shallow coarse sediments in the southern zone, where low numbers of species were found.
\end{abstract}

\section{INTRODUCTION}

A focus upon organisms either attached to, or moving over, hard substrata forms the basis of most of the ideas about the factors affecting abundance and diversity on coral reefs (see reviews by Sale 1980, Connell \& Keough 1985, Huston 1985, Doherty \& Williams 1988). However, lagoons and back-reef regions can be predominantly made up of carbonate sands and gravel (Thomassin 1978). A cursory comparison between reefs and these uniform and superficially barren habitats might suggest that they are an unimportant part of the reef system. On the contrary, recent investigations into the biota of tropical soft sediments indicate abundant and diverse assemblages, including molluscs, crustaceans, echinoderms, polychaetes and nematodes (e.g.

Present addresses:

- Department of Zoology, University of Auckland, Private Bag, Auckland, New Zealand

- Fisheries Research Institute, PO Box 21, Cronulla, 2230 NSW, Australia

-. Department of Zoology, University of New Hampshire, Durham, New Hampshire 03824, USA
Fishelson 1971, Taylor 1971, McWilliam et al. 1981, Jones 1984, Suchanek \& Colin 1986, Jacoby \& Greenwood 1988). These invertebrates fall prey to a variety of teleost and elasmobranch fishes which forage over the sand (Alheit 1981, Alheit \& Scheibel 1982, Suchanek \& Colin 1986, St John et al. 1989). These trophic interactions and the role played by soft sediments in coral reef systems are potentially important, yet poorly understood.

General descriptions of species-habitat relationships in tropical soft sediments, and data on the abundances of broad and arbitrary categories, such as macrofauna or meiofauna, are readily available (e.g. Fishelson 1971, Thomassin et al. 1976, Thomassin 1978, Alheit 1981, Alheit \& Scheibel 1982, Thomassin et al. 1982, Colin 1986, Grelet et al. 1987). However, a quantitative description of pattern is a necessary basis for assessing the importance of ecological processes which limit populations and structure assemblages (Choat 1982, Andrew \& Mapstone 1987). A quantitative approach has only recently been applied to tropical soft sediment communities (Hughes \& Gamble 1977, Faubel 1984, Jones 1984, Suchanek \& Colin 1986, Jacoby \& Greenwood 1988, Riddle 1988). Molluscs may be the most 
important group of invertebrates in these habitats, both in terms of biomass and as a source of food for teleosts. In contrast to the wealth of information on the distribution and abundance of molluscs inhabiting soft-sediments in temperate waters (see Gray 1974, 1981), there are few such studies on equivalent tropical species (but see Taylor 1971). Investigations into the ecological role played by molluscs must be founded upon fundamental information on the species present, their distribution and abundance and the relationship between abundance and features of the habitat.

The main aim of this investigation was to describe spatial patterns in the distribution, abundance and structure of mollusc populations inhabiting the soft sediments of One Tree Lagoon, Great Barrier Reef, Australia. Further, we wished to identify the spatial scales at which these populations respond to the lagoon environment as a preliminary step toward examining the impact of fish predation. The effects of changing the scale of focus, when describing patterns or identifying causal processes, is a major issue in contemporary ecology (see Ogden \& Ebersole 1981, Dayton \& Tegner 1984, Andrew \& Mapstone 1987 for discussions relating to marine systems). An arbitrary decision to focus on any one scale could lead to a complete failure to detect the patterns of most importance to the majority of the species. Given no prior information on these mollusc assemblages, we chose 4 scales, from a broad scale $(10$ $\mathrm{km}^{2}$ ) encompassing the major habitat zones within the lagoon, down to a fine scale $\left(0.1 \mathrm{~m}^{2}\right)$, represented by replicate cores. Quantifying the variance explained by each level in this hierarchy enabled us to identify the scales of most importance, in terms of the magnitude of changes in density and the size-structure of populations.

Spatial patterns in the structure of soft sediment assemblages in temperate regions have primarily been correlated with changes in depth and sediment characteristics (reviewed by Gray 1974, 1981, Whitlach 1981). Recent studies in tropical systems have detected the same sorts of trends (Jones 1984, Grelet et al. 1987). In view of this, sampling at the largest spatial scale was structured in relation to broad zones, distinguished on the basis of depth and sediment characteristics. In addition, measurements of depth and sediment grain size-frequency distributions were made at all sites sampled, to examine the numerical responses of individual species to these environmental factors at each scale.

\section{METHODS}

This study was carried out during October 1985 in the main lagoon of One Tree Reef, near the southern limit of the Great Barrier Reef $\left(23^{\circ} 30^{\prime} \mathrm{S}, 152^{\circ} 06^{\prime} \mathrm{E}\right)$. This lagoon is ca $10 \mathrm{~km}^{2}$ in area, and reaches a depth of $7 \mathrm{~m}$. The lagoon floor primarily consists of carbonate sediments, with the remainder being made up of isolated patchreefs and reticulated reef structures. Sediments of differing coarseness occur in almost concentric bands within the lagoon, with the coarse sand found in shallow water near the perimeter and the finest sediment in the deepest, central region (Davies et al. 1976, Johnstone et al. 1988). For the purposes of sampling, the lagoon was stratified into 5 zones, which could be distinguished on the basis of geographic location, depth and sediment characteristics (Fig. 1). The North Shallow zone (NS) was characterized by relatively coarse sediments ( $>250$ $\mu \mathrm{m}$ ) and reached a mean depth of $2.3 \mathrm{~m}$. South Shallow (SS) had similar sediment composition, but only reached a mean depth of $0.6 \mathrm{~m}$. The Central zone (CN), with an average depth of $3.5 \mathrm{~m}$, was made up of relatively fine sediments $(<125 \mu \mathrm{m})$. North Deep (ND) and South Deep (SD) zones consisted of sediments of intermediate coarseness, the average depths being $2.8 \mathrm{~m}$ at South Deep and $4.2 \mathrm{~m}$ at North Deep.

A pilot survey was conducted at 2 locations in the North deep zone to ascertain to what depth sediment cores needed to be taken to sample molluscs. We wished to determine the appropriate sample unit size necessary to obtain a level of precision of 0.15 given 4 replicate cores. This was obtained following the procedures suggested by Andrew \& Mapstone (1988). The abundances of common molluscs were compared by means of circular cores taken at depths of 5 and $10 \mathrm{~cm}$. We found no significant differences in estimates of mean density for any of the common species, therefore the $5 \mathrm{~cm}$ depth was considered adequate to sample these sub-surface dwelling species. In the shallow zones, the $5 \mathrm{~cm}$ layer of sediment was often the full extent of soft substratum above a compacted rubble layer. Two core sizes were examined, 0.03 and $0.06 \mathrm{~m}^{2}$. The data suggested that a core size slightly larger than $0.06 \mathrm{~m}^{2}$ was necessary to achieve the desired precision for the more abundant species. A core size of $0.1 \mathrm{~m}^{2}$ allowed us to obtain this precision but we recognized that this may have been too small to get meaningful estimates for rarer species. A comparison of the proportions of molluscs collected in nested 3,2 and $1 \mathrm{~mm}$ sieves, indicated that the finest sieve was necessary to retain the smallest size classes. This mesh should retain more than the $1.4 \mathrm{~mm}$ mesh recommended by Thomas$\sin$ (1978) for tropical soft sediments.

A hierarchical sampling design was employed to describe spatial patterns in abundance at 4 scales (Fig. 2). We compared differences between: (1) Broad habitat zones, together encompassing most of a $10 \mathrm{~km}^{2}$ lagoon (see Fig. 1). (2) Random $10000 \mathrm{~m}^{2}$ locations within zones, 100 to $1000 \mathrm{~m}$ apart. (3) Random $25 \mathrm{~m}^{2}$ sites within locations. (4) Random $0.1 \mathrm{~m}^{2}$ cores within sites. A second pilot survey was conducted to deter- 
Fig. 1. Map showing the 5 lagoon zones and locations (A to O). Surrounding graphs show the mean sediment grain size composition for the 5 zones. Proportions are based on weight in each of the $1 \phi$ classes

mine both the total number of samples which could be collected and sorted within a $2 \mathrm{wk}$ period, and the best way to allocate this effort among sites and locations. During May 1985, we sampled 2 zones, 2 locations, and 3 sites, with 4 replicates from each. This indicated that we could process ca 120 cores in the time available. It also showed that zones explained much more of the variance present than the lower levels. By sampling 3 locations and 2 sites within each location, the 120 replicates were distributed in such a way as to put maximum effort into the levels where most of the variation occurred, while maximizing the power of the test for differences among zones (procedures recommended by Underwood 1981) (Fig. 2).

The 4 replicate $0.1 \mathrm{~m}^{2}$ cores from each site were collected using a diver-operated air lift attached to a SCUBA cylinder (Thomassin 1978). The sediment was deposited in nylon bags with a $1 \mathrm{~mm}$ mesh diameter. All living macrofauna were fixed in formaldehyde and simultaneously stained with Beibrich scarlet, to enhance visibility for sorting. All molluscs were extracted from the sediment, identified to species level and counted. Selected abundant species were also measured: bivalves - Tellina robusta, $T$. cf. myaformis, Exotica rhomboides, E. cf. virgulata, Fragum fragum and Fragum sp.; gastropods - Umbonium guamensis, Rhinoclavis aspera and Pupa nitidula. A complete check-list of molluscan fauna from this sampling programme appears in Table 1.

At each site, depth was measured at low tide and two
$50 \mathrm{ml}$ jars of sediment were collected from random positions. These samples were processed to quantify structure following the methods outlined by Folk (1974) for carbonate sediments. Samples, which were stored in ethanol, were first dried to a constant weight (ca $7 \mathrm{~d}$ at $60^{\circ} \mathrm{C}$ ) and then wet-sieved through a $63 \mu \mathrm{m}$ screen to remove the silt fraction. The collected sand sample was dried, re-weighed and separated into fractions with $1 \phi$ intervals by shaking for $10 \mathrm{~min}$ on a geological sieve shaker. Each fraction was then weighed separately to measure the proportion of sediment in 6 size categories

\section{RESULTS}

\section{Taxonomic composition}

The mollusc assemblage on One Tree Lagoon was found to be rich in species, with a total of 69 species distributed among 27 families recorded in the pilot and main surveys (Table 1). The most speciose families were the bivalve family Tellinidae ( 8 species), and the gastropod families Cerithiidae ( 7 species) and Naticidae ( 7 species).

In terms of the numbers of individuals, the assemblage was dominated by 5 tellinid bivalves, including Tellina robusta, T. obtusalis, T. cf. myaformis, Exotica rhomboides and E. cf. virgulata, the cardiid Fragum sp., and 4 gastropods in separate families - Pupa nitidula (Actaeonidae), Rhinoclavis aspera (Cerithiidae), Umbonium guamensis (Trochidae) and Atys cylindricus
Fig. 2. Hierarchical sampling programme showing the main sampling levels and relationships between them. Four replicate cores were taken at each site

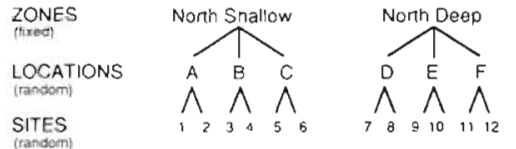
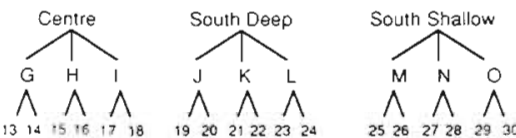
Table 1. Molluscs found in sediments of One Tree Lagoon, Great Barrier Reef

\section{GASTROPODA}

ARCHAEOGASTROPODA

Trochidae

Chrysostoma paradoxum (Born, 1780)

Mesoclanculus sp

Umbonium guamensis (Quoy \& Gaimard, 1834)

\section{Neritidae}

Nerita sp

\section{MESOGASTROPODA}

Cerithiidae

Cerithium alveolus Hombron \& Jacquinot, 1854

Cerithium columna Sowerby, 1834

Cerithium sp

Clypeomorus zonatus Wood, 1828

Rhinoclavis aspera (Linné, 1758)

Rhinoclavis fasciata (Brugierè, 1792)

Rhinoclavis vertagus Linné, 1758

\section{Eulimidae}

Eulima sp.

\section{Strombidae}

Strombus gibberulus (Linné, 1758)

Strombus luhuanus Linné, 1758

Terebellum terebellum (Linné, 1758)

\section{Naticidae}

Natica bougei Sowerby, 1908

Natica gualteriana Recluz, 1844

Natica onca (Röding, 1798)

Natica sp. 1

Natica sp. 2

Polinices flemingiana (Recluz, 1844)

Polinices tumidus (Swainson, 1840)

\section{NEOGASTROPODA}

Pyrenidae

Mitrella ligula (Duclos, 1840)

\section{Nassariidae}

Nassarius albescens (Dunker, 1846)

Nassarius ecstilbus (Melvill \& Standen, 1896)

Nassarius shacklefordi (Melvill \& Standen, 1896)

Nassarius spendidulus (Dunker, 1846)

\section{Olividae}

Amalda cf. edithae (Pritchard \& Gatliff, 1899)

Olivella sp.

\section{Volutidae}

Amoria maculata Swainson, 1822

Cymbiolacca pulchra Sowerby, 1825

\section{Marginellidae}

Granula sp.

\section{Turridae}

Clavus leforestieri (Hervier, 1896)

Eucithara delacouriana (Crosse, 1896)

Eucithara funiculata (Reeve, 1846)

Lophiotoma acuta (Perry, 1811)

\section{Conidae}

Conus spectrum (Linné, 1738)

\section{ENTOMOTAENIATA}

Pyramidellidae

Pyramidella acus (Gmelin, 1791)

CEPHALASPIDEA

\section{Acteonidae}

Pupa alveola (Souverbie, 1863)

Pupa nitidula (Lamarck, 1916)

Pupa solidula (Linné, 1758)

Pupa sulcata (Gmelin, 1791)

\section{Scaphandridae}

Tornatina sandwichensis Pease, 1860

Tornatina sp.

\section{Atyidae}

Atys cylindricus (Helbing, 1779)

BASOMMATOPHORA

Ellobiidae

Allochroa layardi (H. \& A. Adams, 1855)

\section{BIVALVIA}

SOLEMYOIDA

Solemyidae

Solemya sp.

MYTILOIDA

Limidae

Limidae sp.

VENEROIDA.

\section{Lucinidae}

Anodontia (Cavatidens) omissa (Iredale, 1930) Unidentified sp. 1

\section{Kelliidae}

Kellia sp.

\section{Cardiidae}

Fragum fragum (Linné, 1758)

Fragum sp.

Fulvia radiata

Mesodesmatidae

Ervillea sp.

\section{Tellinidae}

Exotica (Loxoglypta) rhomboides (Quoy \& Gaimard, 1834)

Exotica c.f. virgulata (Hanley, 1845)

Tellina robusta (Hanley, 1844)

Tellina (Cadella) obtusalis Destayes, 184.5

Tellina (Abranda) cf. myaformis Sowerby, 1868

Tellina (Scissulina) dispar (Conrad, 1837)

Tellina (Quadrans) parvitas (Iredale, 1937)

Tellina (Cadella) semen (Hanley, 1.844)

\section{Semelidae}

Semele sp.

\section{Veneridae}

Dosinia extranea (Iredale, 1937)

Lioconcha ornata (Lamarck, 1817)

Timocla (Glycydonta) marica (Linnaeus, 1758)

Callista (Callista) semisulcata (Sowerby, 1857)

Circe cf. scripta (Linné, 1758) 
(Atyidae). Together, these 10 species comprised $76 \%$ of the individuals collected.

\section{Population abundance and structure}

Detailed descriptions were made of spatial pattern in the distribution and abundance of the 10 most common species. No species was cosmopolitan in its dis-
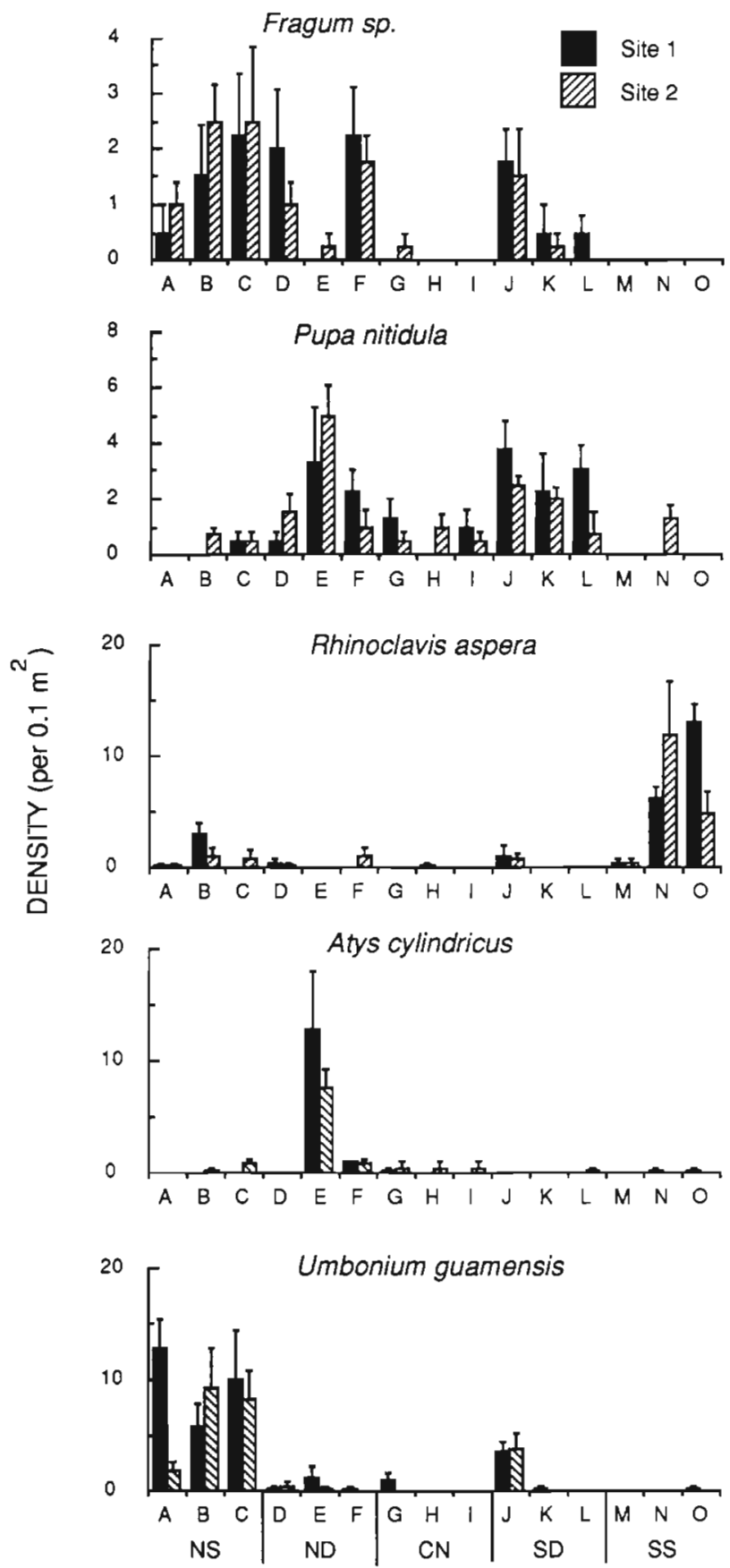

LOCATION AND ZONE tribution. Differences in density were observed at all spatial scales examined (Fig. 3, Table 2). Nine of the 10 species exhibited significant differences among zones; 6 of the 10, significant differences among locations; and 7 of the 10, significant differences among sites (Table 2). These spatial scales were not, however, equally important in terms of the magnitude of the variation observed. Zones explained between 50 and
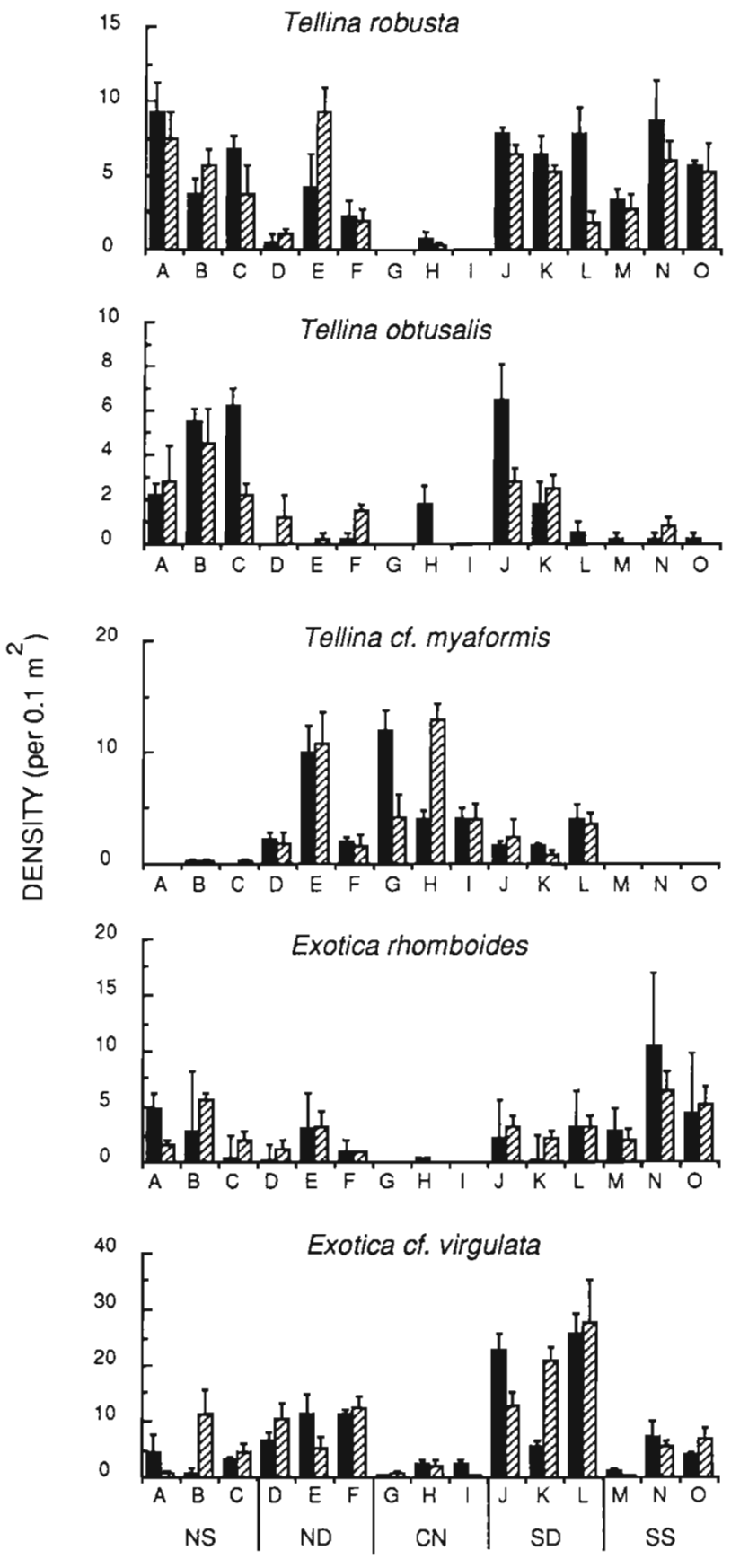

LOCATION AND ZONE

Fig. 3. Mean densities (per $0.1 \mathrm{~m}^{2} \pm \mathrm{SE}$ ) of 10 common molluscs within each zone, location (A to O) and site. For clarity, the 2 random sites within each location are represented by solid and cross-hatched histograms 
$85 \%$ of the variation in numbers for all species except Atys cylindricus. A. cylindricus exhibited a location effect only, and locations explained $72 \%$ of the variance observed (Table 2). Excluding A. cylindricus, locations explained an average of $16 \%$ of the variance, sites $7 \%$ and replicates $15 \%$. Hence, the varia- tion in numbers declines fairly dramatically with decreasing scales of focus between zones and sites.

There were substantial differences among species in their distributions among zones (Fig. 3). The 5 common tellinids each showed a unique pattern. Tellina robusta was the most widespread, being abundant in

Table 2. Analyses of variance of abundance for 10 species of mollusc in One Tree Reef lagoon. All data were transformed $\sqrt{\mathrm{x}+1}$ for F-ratios but untransformed data were used for calculation of percent variance explained at each level Cochran's value denoting significant heterogeneity of variances for these samples $=0.16$. Degrees of freedom for each F-ratio shown in parentheses. $p<0.05$. Percentage variance explained, calculated as described by Underwood (1981)

\begin{tabular}{|c|c|c|c|c|c|c|c|c|}
\hline \multirow[t]{2}{*}{ Species } & \multirow{2}{*}{$\begin{array}{c}\text { Cochran's } \\
\text { value }\end{array}$} & \multicolumn{3}{|c|}{ F-ratio } & \multicolumn{4}{|c|}{ Percent variance explained } \\
\hline & & $\begin{array}{c}\text { Zone } \\
(4,10)\end{array}$ & $\begin{array}{c}\text { Loc } \\
(10,15)\end{array}$ & $\begin{array}{c}\text { Site } \\
(15,90)\end{array}$ & Zone & Loc. & Site & Rep \\
\hline Tellina robusta & 0.11 & $6.78^{\circ}$ & $2.79^{\circ}$ & $2.17^{\circ}$ & 0.60 & 0.17 & 0.07 & 0.15 \\
\hline T. obtusalis & 0.20 & $5.83^{*}$ & 2.08 & $3.61^{\circ}$ & 0.65 & 0.12 & 0.11 & 0.11 \\
\hline T. cf. myaformis & 0.12 & $6.26^{\circ}$ & $3.26^{\circ}$ & $2.84^{\circ}$ & 0.58 & 0.20 & 0.13 & 0.09 \\
\hline Exotica rhomboides & 0.18 & $5.03^{\circ}$ & $3.11^{\circ}$ & $1.96^{\circ}$ & 0.55 & 0.25 & 0.06 & 0.15 \\
\hline E. cf. virgulata & 0.16 & $13.1^{\bullet}$ & 1.48 & $3.19^{\circ}$ & 0.79 & 0.04 & 0.08 & 0.08 \\
\hline Fragum sp. & 0.16 & $3.90^{\circ}$ & $8.61^{\circ}$ & 0.41 & 0.51 & 0.28 & 0 & 0.31 \\
\hline Pupa nitidula & 0.22 & $6.40^{\circ}$ & 1.78 & 1.64 & 0.59 & 0.15 & 0.03 & 0.23 \\
\hline Atys cylindricus & 0.57 & 1.35 & $25.3^{\circ}$ & 0.93 & 0.09 & 0.72 & 0 & 0.20 \\
\hline Rhinociavis aspera & 0.47 & $4.14^{\circ}$ & $4.60^{\circ}$ & $2.14^{\circ}$ & 0.60 & 0.20 & 0.10 & 0.10 \\
\hline Umbonium guamensis & 0.24 & 19.1 ${ }^{\circ}$ & 1.07 & $3.00^{\circ}$ & 0.85 & 0 & 0.09 & 0.12 \\
\hline
\end{tabular}
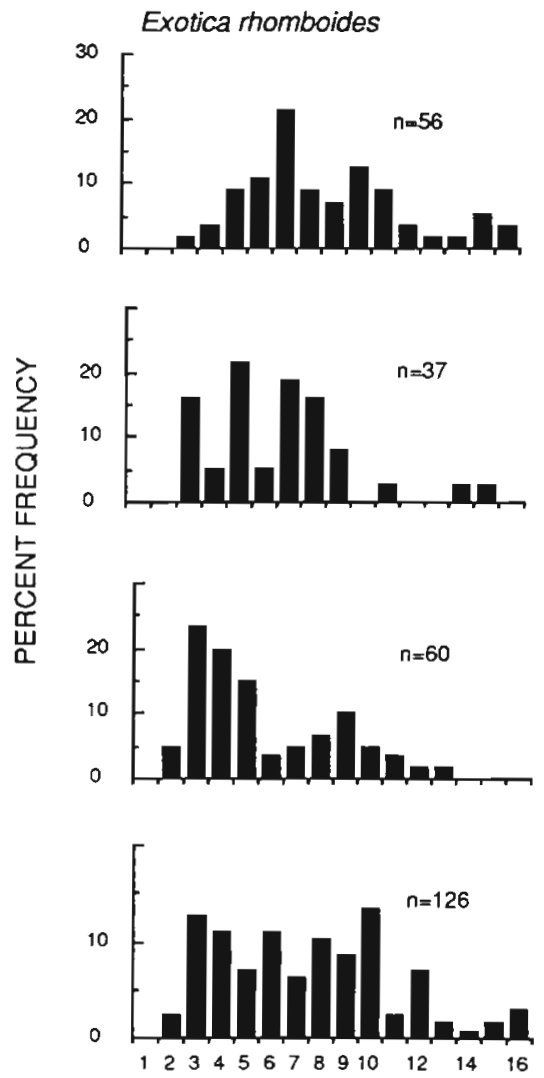
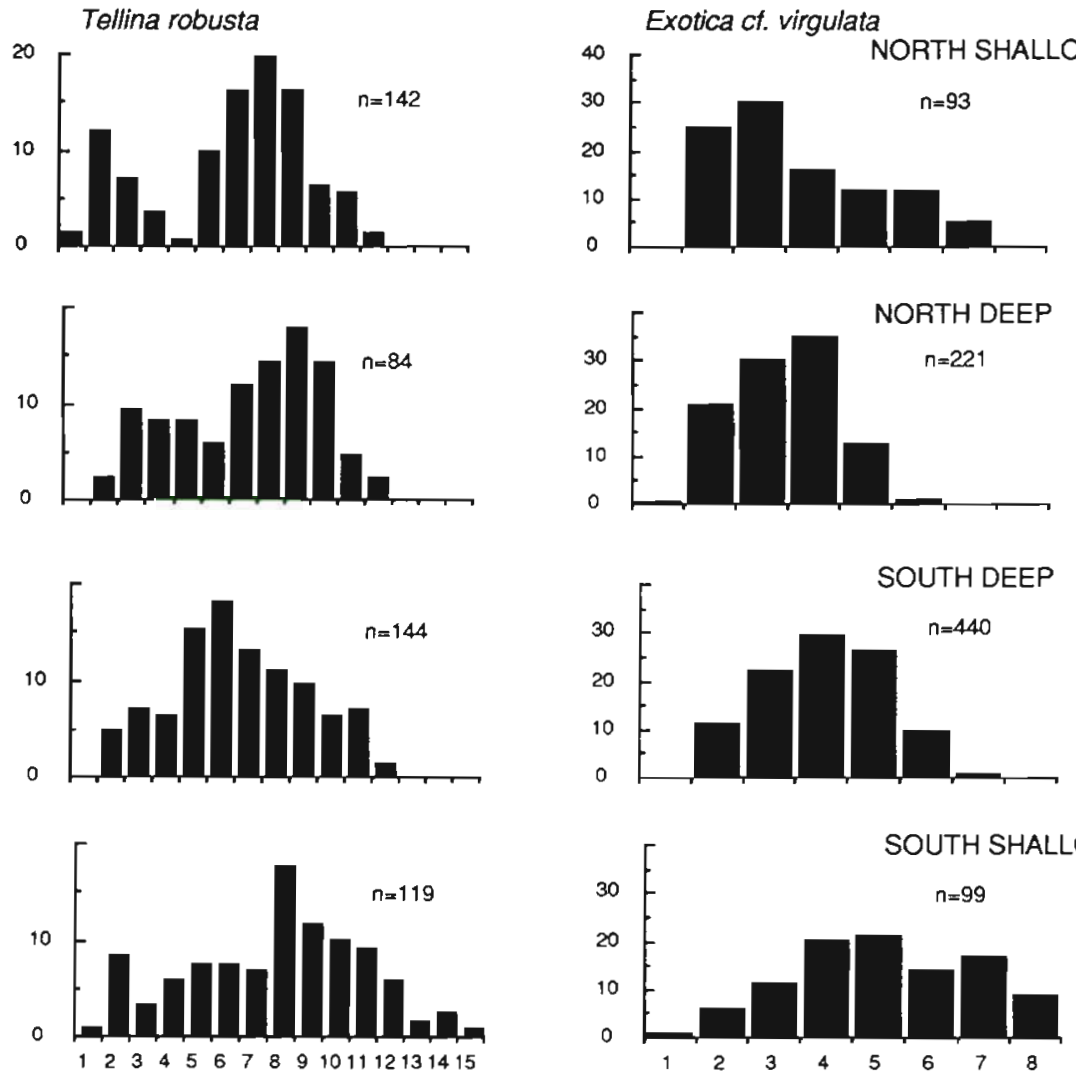

\section{SIZE CLASS $(\mathrm{mm})$}

Fig. 4. Percent frequency of individuals, in $1 \mathrm{~mm}$ size classes, for 3 tellinid bivalve species collected from 4 zones - Vorth Shallow, North Deep, South Deep and South Shallow. Low numbers of these species in the Centre zone procludes any comparison 
all zones except the centre, where $T$. cf. myaformis dominated. T. obtusalis was most common in NS and Exotica rhomboides at SS, with E. cf. virgulata reaching peak abundances in the deeper channels of ND and SD. Of the other species examined, Fragum sp. and Umbonium guamensis were most abundant at NS, Rhinoclavis aspera at SS, and Pupa nitidula at ND and SD. Nearly all the Atys cylindricus at counted were confined to one location in the ND channel.

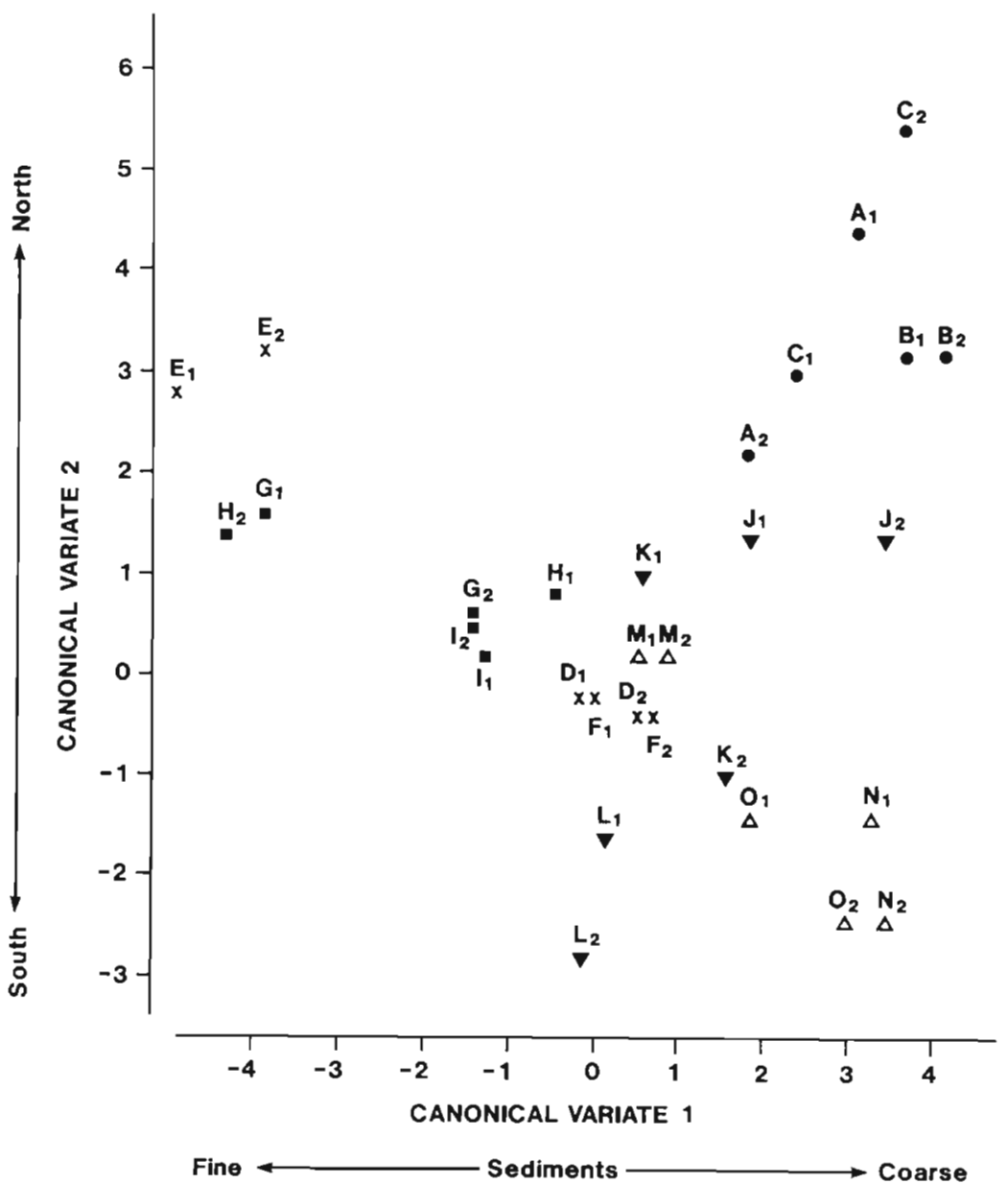

There were also consistent patterns among species in population size-structure (Fig. 4). The tellinid bivalves common to the shallow and deep zones of the northern and southern halves of the lagoon, all reached larger sizes in the south shallow zone. The other species were too restricted in their distributions to detect such patterns, although location and site differences in population structure appeared to be common.
Fig. 5. Canonical discriminant analysis for maximal separation of sampling locations (A to $O)$ and sites $(1,2)$ based on the abundances of the 10 common molluscs plotted in Fig. 3. Canonical variate 1 ( $\mathrm{x}$-axis) vs canonical variate 2 (y-axis) (see Williams 1983). North.

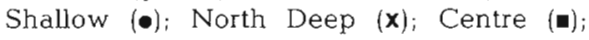
South Deep ( $\mathbf{v})$; South Shallow $(\Delta)$

Table 3. Pearson's correlation matrix between pairs of species, in terms of mean abundance for the 30 sites. Species were: (T. r.) Tellina robusta; (T. o.) T obtusalis; (T. m.) T. cf. myaformis; (E. r.) Exotica rhomboides; (E. v.) E. cf. virgulata; $(F$. sp.) Fragum sp.; (P. n.) Pupa nitidula; (A. C.) Atys cylindricus; (R. a.) Rhinoclavis aspera; and (U. g.) Umbonium guamensis. Correlations shown in boldface are significant at $p=0.05$ level for single paired comparisons

\begin{tabular}{|c|c|c|c|c|c|c|c|c|c|}
\hline Species & T. $r$ & T. $O$ & $T . m$. & E. $I$. & E. $v$. & F. sp. & p. $n$. & A. C. & R. a. \\
\hline To. & +0.40 & & & & & & & & \\
\hline$T m$ & -0.31 & -0.38 & & & & & & & \\
\hline E. $r$. & +0.63 & 0 & -0.35 & & & & & & \\
\hline E. V. & 0.25 & 0.15 & -0.06 & 0.21 & & & & & \\
\hline F. sp. & 0.11 & +0.63 & -0.35 & -0.14 & 0.15 & & & & \\
\hline P. $n$. & 0.31 & 0.06 & +0.46 & -0.08 & +0.50 & 0.07 & & & \\
\hline A. C. & 0.13 & -0.21 & +0.54 & 0.05 & 0.04 & -0.16 & +0.55 & & \\
\hline R. $a$. & 0.27 & -0.1 & -0.33 & +0.61 & -0.12 & -0.22 & -0.25 & -0.13 & \\
\hline U. g. & +0.39 & +0.68 & -0.30 & 0.14 & -0.08 & +0.57 & -0.16 & -0.09 & -0.13 \\
\hline
\end{tabular}




\section{Species associations and richness}

The Pearson's correlation matrix for these 10 species, based upon the means for each site, indicated various positive and negative associations among species (Table 3). Tellina cf. myaformis, Atys cylindricus and Pupa nitidula are all positively associated, being common to the ND, CN and SD zones. Rhinoclavis aspera and Exotica rhomboides, which are both abundant at SS, are positively correlated. Several species common to NS, including T. robusta, T. obtusalis, E. rhomboides, Fragum sp. and Umbonium guamensis also tend to be positively correlated in occurrence.

A canonical discriminant analysis (CDA) was carried out to assess, objectively, whether zones represent discrete homogeneous assemblages, and describe any trends in the overall change in species composition across the lagoon (Fig. 5). CDA is commonly used in ecology to explore pattern in multivari- ate data, by reducing it to 1 or 2 dimensions (canonical variates). Canonical variates are linear combinations of the measurement variables (abundances), which maximize discrimination among groups (sites) (Williams 1983). The CDA displayed trends in the data which were not immediately obvious from the observations on individual species (Fig. 5). The first canonical variate (x-axis) explained $34 \%$ of the total variation and appeared to separate sites along a gradient from the very fine sediments of $\mathrm{CN}$, and location $\mathrm{E}$ within ND (dominated by Tellina cf. myaformis and Atys cylindricus) to the coarse sediments of NS and SS (characterized by $T$. obtusalis, Exotica rhomboides and others). The second canonical variate (yaxis), which explained $22 \%$ of the variation, appears to identify a trend from our northern to our southern zones. Large positive values represent the NS assemblage dominated by $T$. botusalis and Umbonium guamensis, and large negative values, sites

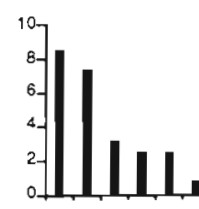

A
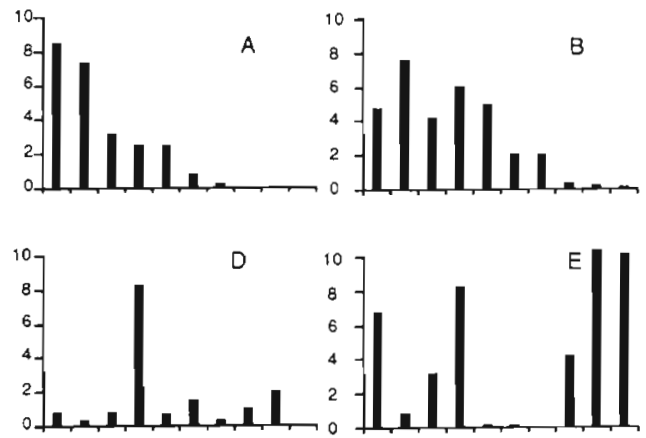

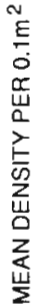
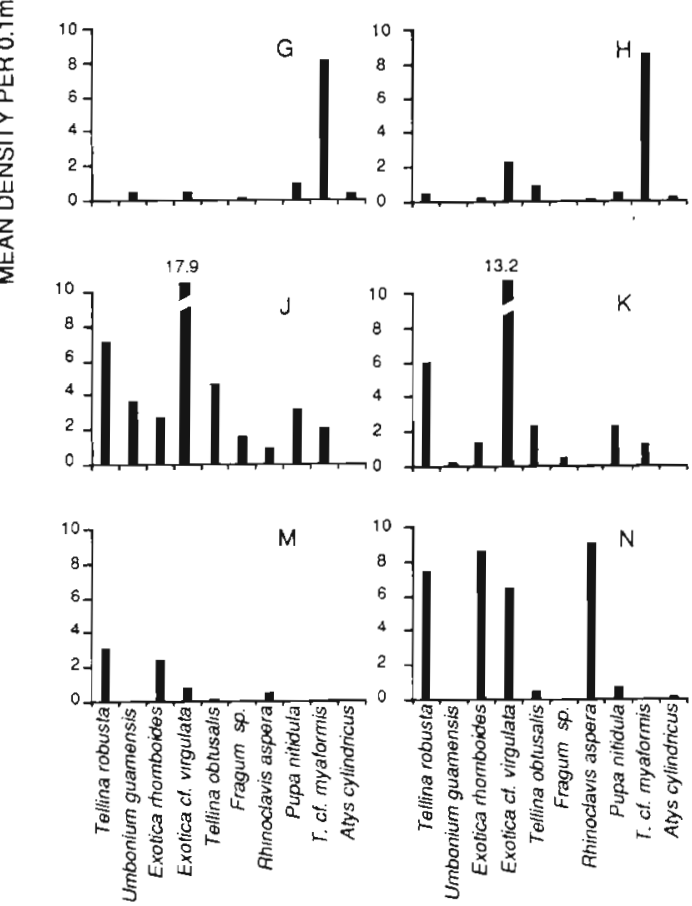

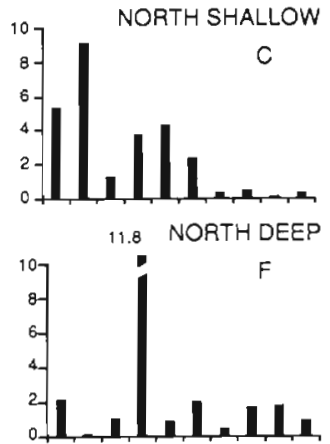

CENTRE
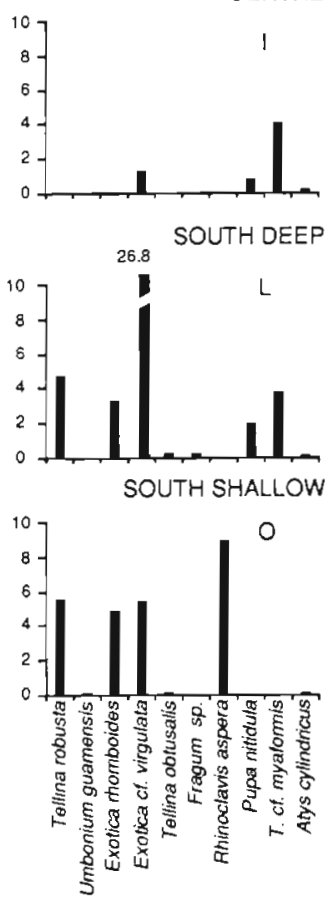

Fig. 6. Species identity vs mean density curves for pooled sites within each location (A to O), within each of the 5 lagoon zones. Species are ranked in order of decreasing abundance for North Shallow, Location A 
dominated by E. cf. virgulata in $\mathrm{SD}$ and Rhinoclavis aspera at SS.

On the basis of these 2 trends, detected by the $\mathrm{CDA}$, zones were separated in terms of their composition, and sites within locations were very similar (Fig. 5). The degree of separation of locations was variable, but somewhat intermediate between zones and sites. Only the NS and $\mathrm{CN}$ zones appeared to represent homogeneous assemblages. All locations at NS were dominated by a diverse assemblage including Tellina robusta, T. obtusalis, Exotica rhomboides, E. cf. virgulata, Fragum sp. and the gastropod Umbonium guanensis (Fig. 6). A single species, Tellina cf. myaformis, dominated all locations at the Centre (Fig. 6).

For the other 3 zones, locations did not fall into well defined groupings (Fig. 5). The precise differences upon which locations were separated, are best viewed by examining species versus abundance plots for each location in these zones (Fig. 6). In ND, for example, location E differed substantially from $\mathrm{D}$ and $F$ due to the presence of high densities of Tellina cf. myaformis and Atys cylindricus. Exotica rhomboides was the only species abundant at all locations. In SS, 2 nearby locations, $\mathrm{N}$ and $\mathrm{O}$, were nearly identical, being dominated by the gastropod Rhinoclavis aspera and the 3 tellinids $T$. robusta, E. rhomboides and $E$. cf. virgulata. The other location, $M$, was extremely depauperate by comparison. The reasons for these location differences are not clear, but they may represent long-shore trends in species composition. Location $\mathrm{E}$ was quite distant from the other 2 in the ND zone, and was the only area covered in a thin mat of algae.

There were apparent differences in species richness among zones (Fig. 7). Greatest species richness was observed in the NS zone and the lowest at the $\mathrm{CN}$ zone. Species richness was also relatively low at SS, but tended to be intermediate in the deep channels.

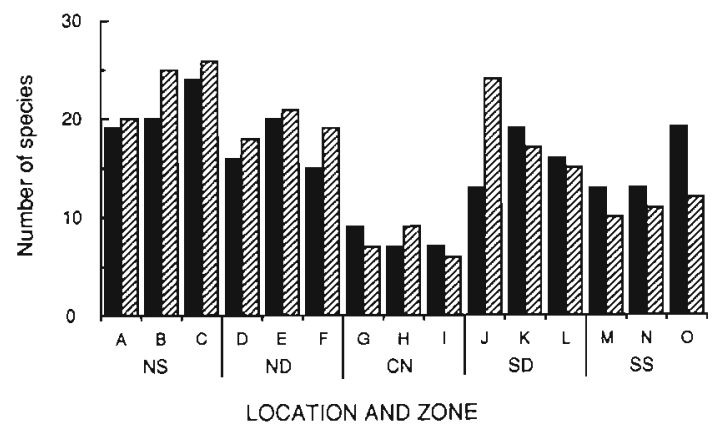

Fig. 7. Total number of species recorded within each zone, location (A to $O$ ) and site. For clarity, the 2 random sites within each location are represented by solid and cross-hatched histograms
Table 4. Correlations between physical parameters $(A)$, and between physical parameters and abundance (B) for 10 species (see legend of Table 3 for species codes). Correlations significant at $p=0.05$ for single paired comparisons in boldface

\begin{tabular}{|c|c|c|c|}
\hline \multicolumn{4}{|l|}{ A } \\
\hline \multicolumn{3}{|c|}{ Mean grain size vs sand-silt ratio } & $r=+0.52$ \\
\hline \multicolumn{3}{|c|}{ Mean grain size vs depth } & 0.53 \\
\hline \multicolumn{3}{|c|}{ Sand-silt ratio vs depth } & 0.72 \\
\hline B & Mean grain & Sand-silt & Depth \\
\hline Species & size & ratio & \\
\hline$T . r$ & +0.38 & 0.33 & -0.33 \\
\hline T. o. & +0.44 & 0.14 & -0.10 \\
\hline$T . m$ & -0.56 & -0.50 & +0.60 \\
\hline E. $r$. & 0.24 & +0.48 & -0.61 \\
\hline E. V. & -0.35 & -0.23 & 0.15 \\
\hline F. sp. & 0.32 & 0 & 0.18 \\
\hline P. n. & -0.49 & -0.44 & +0.55 \\
\hline A. C. & -0.21 & -0.20 & +0.47 \\
\hline R. a. & 0.14 & +0.73 & +0.62 \\
\hline U. $g$. & +0.40 & 0.22 & -0.08 \\
\hline
\end{tabular}

\section{Associations with depth and sediment characteristics}

Changes in species composition, abundance and population-structure among zones were clearly associated with changes in water depth and sediment characteristics (Fig. 1). However, there were also subtle differences in these parameters among locations and sites. The closeness of correlations between abundances, depth and 2 commonly used measures of sediment coarseness (mean grain size and the sand/silt ratio) were examined for each of the 10 common species (Table 4). As expected, the measures of sediment coarseness were positively correlated, and they were both negatively correlated with depth. Five species were significantly correlated with at least one of the measurements of increasing sediment coarseness, including Tellina robusta, T. obtusalis, Exotica rhomboides, Rhinoclavis aspera, and Umbonium guamensis - all species common in at least one of the two shallow zones. Negative correlations for Pupa nitidula and T. cf. myaformis indicated an association with finer sediments. $R$. aspera and E. rhomboides, which characterized SS, were negatively correlated with depth. The abundance of $T$. cf. myaformis, Atys cylindrica and $P$. nitidula increased with depth.

\section{DISCUSSION}

The mollusc assemblage within the soft sediments of the lagoon at One Tree Reef proved to be rich in species (69), with a number of these reaching very high densities (up to $250 \mathrm{~m}^{-2}$ ). These values appear to be comparable to other tropical reef sediments for which 
numerical data have been published (Taylor 1971, Salvat 1972). Unfortunately, since the review by Thomassin (1978), little quantitative work has been done on these assemblages.

The abundances of marine organisms are characteristically variable at a number of spatial scales (Andrew \& Mapstone 1987). Frequently, quantitative sampling programmes are inadequate to distinguish one scale of variability from another (Hurlbert 1984). Such confusion can lead to incorrect conclusions about processes structuring communities, and cause avoidable debate over issues which are scale dependent (e.g. Ogden \& Ebersole 1981, Sale \& Douglas 1984). The hierarchical survey employed in this study provided a clear method of distinguishing variability among strata at progressively larger scales from the variation within these strata at each level (Underwood 1981, Andrew \& Mapstone 1987). Such nested designs have been used effectively in detecting the scale at which species respond to their environment in a number of ecological surveys (e.g. Caffey 1985, Choat \& Bellwood 1985, Phillips \& Fleeger 1985).

In terms of changes in abundance and species composition, the most dramatic changes occurred at the largest scale examined (between habitat zones). This scale accounted for between 50 and $85 \%$ of the variation in abundance, for all but one species examined. There was moderate variation on an intermediate scale (among broadly spaced 1 ha locations within zones), and considerably less variation within locations (among sites within locations). This suggests that the most important factors affecting the distribution and abundance of this fauna operate on a relatively broad spatial scale in this lagoon.

It was not possible to directly attribute the large scale variation of features of the habitat (habitats were not replicated). Depth and sediment type are clearly associated with abundance patterns in this system, however any causal effects on species distributions would have to be assessed experimentally. This is a recurring feature of mollusc communities, whether arctic (e.g. Carey et al. 1984), temperate (e.g. Richter \& Sarnthein 1977. Oliver et al. 1980) or tropical (e.g. Taylor 1971. Thomassin et al. 1982, Grelet et al. 1987). Although not necessarily causative factors in themselves, depth and sediment are clearly correlated with the factors responsible for determining species distributions. Species-specific settlement preferences, either for different sediment types, for different depths or other unknown but correlated factors, are an obvious potential mechanism causing the observed distributions (Gray 1974). Experimental sediment transplants, such as that carried out by Richter \& Sarnthein (1977) in the Wadden Sea, may be the only way to separate these factors, in terms of their relative importance.
Changes in depth and sediment composition usually relate to changes in a host of other physical factors (e.g. water movement, oxygen supply, nutrients) (Richter \& Sarnthein 1977, Johnstone et al. 1988). These in turn may affect a range of biological factors, such as the accumulation of detritus, productivity and microbial activity; physical factors may mediate disturbance or predator effects, whether by epibenthic organisms (e.g. Commito 1982, Arnold 1984) or fish (Van Blaricom 1982, Jones et al. 1988). The scales at which all these potentially important variables operate need to be considered before meaningful experiments can be designed to examine their impact. Those factors exhibiting recognizable patterns in their intensity at larger scales would be primary targets for future research.

This study was conceived primarily as a basis for a future assessment of the role soft-sediment molluscs play in coral-reef food-chains. Although potential epibenthic predators, such as crabs and naticid gastropods, were frequently encountered in samples, numbers were too low to get a clear idea of their patterns of distribution. It has been suggested that naticids play an important role as predators in other tropical soft sediment areas (Berry 1982). Spatial variation in the abundance and feeding intensity of teleosts known to consume soft sediment molluscs have been investigated at One Tree Reef (Jones et al. 1988, unpubl.). These studies showed that there was considerable variation in teleost feeding pressure, on both zone and location scales, but little evidence of a major impact of teleosts on prey numbers, either in shallow or deep regions of the lagoon.

Species-specific patterns of change in abundance at progressively larger scales, lead to fairly predictable species groupings in some zones. However, zones do not appear to be homogeneous assemblages in terms of their biotic structure. Considerable variability in species composition was apparent, from location to location, due to the patterns exhibited by some species (e.g. Atys cylindricus was common at one location only). Trends in species richness across the lagoon may also reflect responses of individual species. Increasing species richness in relation to increasing sediment coarseness is a recurring pattern in soft sediment communities (see Gray 1974). Our finding of low diversity in the fine sediments of the centre of the lagoon, and high diversity in the coarse sediments of the northern periphery, is consistent with this. However, low species numbers in the coarse, shallow sediments to the south would not be expected on the basis of this generalization.

This paper presents a static picture of the abundance and structure of mollusc populations in One Tree Lagoon. The obvious extension of this study, an exami- 
nation of whether the patterns present at each scale remain coherent over time, is currently under way (Jones et al. unpubl.). However, the large-scale trends in species and sediment composition across the lagoon are sufficient to suggest a number of testable hypotheses about processes important in tropical soft sediment systems. This is a first step in an understanding of the relationship between these poorly known communities and the adjacent coral reefs.

Acknowledgements. We thank K. Lamprell, B. Long, W. Ponder and G. Richard for helping us identify difficult species. We also thank the following people who spent many hours helping us collect and process the samples: P. Butcher, C. Hayward, L. Howitt, U. Kaly, D. Lizka, D. Meadows, M. Milicich, M. Norman, and P. Smith. The manuscript was improved by comments from N. Andrew, R. Cole, L. Howitt, B. McArdle, A. Jones, G. Skilleter and L. Stocker. This research was supported by a Marine Sciences and Technologies Grant, and is a contribution from the University of Sydney's One Tree Island Field Station

\section{LITERATURE CITED}

Alheit, J. (1981). Feeding interactions between coral reef fishes and the zoobenthos. Proc. 4th int. Coral Reef Symp., Manila 2: 545-552

Alheit, J., Scheibel, W. (1982). Benthic harpacticoids as a food source for fish. Mar. Biol. 70: 141-147

Andrew, N. L., Mapstone, B. D. (1987). Sampling and the description of spatial pattern in marine ecology. Oceanogr. mar. Biol. A. Rev. 25: 39-90

Arnold, W S. (1984). The effects of prey size, predator size, and sediment composition on the rate of predation of the blue crab, Callinectes sapidus Rathbun, on the hard clam, Mercenaria mercenaria (Linne). J. exp. mar Biol. Ecol. 80: 207-219

Berry, A. J. (1982). Predation by Natica maculosa Lamarck (Naticidae: Gastropoda) upon the trochacean gastropod Umbonium vestiarum (L.) on a Malaysian shore. J. exp. mar. Biol. Ecol. 64: 71-89

Caffey, H. M. (1985). Spatial and temporal variation in settlement and recruitment of intertidal barnacles. Ecol. Monogr. 55: 313-332

Carey, A. G. Jr, Scott, P. H., Walters, K. R. (1984). Distributional ecology of shallow southwestern Beaufort Sea (Arctic Ocean) bivalve Mollusca. Mar. Ecol. Prog. Ser. 17: 125-134

Choat, J. H. (1982). Fish feeding and the structure benthic communities in temperate waters. A. Rev. Ecol. Syst. 13: 423-449

Choat, J. H., Bellwood, D. R. (1985). Interactions amongst herbivorous fishes on a coral reef: influence of spatial variation. Mar. Biol. 89: 221-234

Colin, P. L. (1986). Benthic community distribution in the Enewetak Atoll lagoon, Marshall Islands. Bull. mar. Sci. 38: $129-143$

Commito, J. A. (1982). Effects of Lunatia heros predation on the population dynamics of Mya arenaria and Macoma balthica in Maine, USA. Mar. Biol. 69: 187-193

Connell, J. H., Keough, M. J. (1985). Disturbance and patch dynamics of subtidal marine animals on hard substrata. In: Pickett, S. T A., White, P. S. (eds.) The ecology of natural disturbance and patch dynamics. Academic Press, New York, p. 101-124
Davies, P. J., Radke, B. M., Robison, C. R. (1976). The evolution of One Tree Reef, southern Great Barrier Reef, Queensland. BMR J. Aust. Geol. Geophys. 1. 231-240

Dayton, P. K., Tegner, M. J. (1984). The importance of scale in community ecology: a kelp forest example with terrestrial analogs. In: Price, P. W., Slobodchikoff, C. N., Gaud, W. S. (eds.) A new ecology: novel approaches to interactive systems. Wiley, New York, p. 457-481

Doherty, P. J., Williams, D. McB. (1988). The replenishment of coral reef fish populations. Oceangr. mar. biol. A. Rev., 26: 487-551

Faubel, A. (1984). On the abundance and activity pattern of zoobenthos inhabiting a tropical reef area, Cebu, Philippines. Coral Reefs 3: 205-213

Fishelson, L. (1971). Ecology and distribution of the benthic fauna in the shallow waters of the Red Sea. Mar. Biol. 10: $113-133$

Folk, R. L. (1974). Petrology of sedimentary rocks. Hemphill, Austin

Gray, J. S. (1974). Animal-sediment relationships. Oceanogr. mar. biol. A. Rev. 12: 223-261

Gray, J. S. (1981). The ecology of marine sediments. Cambridge University Press, Cambridge

Grelet, Y., Falconetti, C., Thomassin, B. A., Vitiello, P., Abu Hilal, A. H. (1987). Distribution of the macro- and meiobenthic assemblages in the littoral soft-bottoms of the Gulf of Aqaba (Jordan). Atoll Res. Bull. 308: 1-14

Hughes, R. N., Gamble, J. C. (1977). A quantitative survey of the biota of intertidal soft substrata on Aldabra Atoll, Indian Ocean. Phil. Trans. R. Soc. (Ser. B.) 279: 327-355

Hurlbert, S. H. (1984). Pseudoreplication and the design of ecological field experiments. Ecol. Monogr. 54: 187-211

Huston, M. A. (1985). Patterns of species diversity on coral reefs. A. Rev. Ecol. Syst. 16: 149-177

Jacoby, C. A., Greenwood, J. G. (1988). Spatial, temporal, and behavioural patterns in emergence of zooplankton in the lagoon of Heron Reef, Great Barrier Reef, Australia. Mar Biol. 97: 309-328

Johnstone, R. W., Koop, K., Larkum, A. W. D. (1988). Distribution of organic carbon and inorganic nitrogen in sediments on a coral reef lagoon. Proc. Linn. Soc. 110: 219-227

Jones, A. R. (1984). Sedimentary relationships and community structure of benthic crustacean assemblages of reef-associated sediments at Lizard Island, Great Barrier Reef. Coral Reefs 3: 101-111

Jones, G. P., Sale, P. F., Ferrell, D. J. (1988). Do large carnivorous fishes affect the ecology of macrofauna in shallow lagoonal sediments? A pilot experiment. Proc. 6th int. Coral Reef Congr., Townsville, 2: 77-82

McWilliam, P. S., Sale, P. F., Anderson, D. T. (1981). Seasonal changes in resident zooplankton sampled by emergence traps in One Tree Lagoon, Great Barrier Reef. J, exp. mar. Biol. Ecol. 52: 185-203

Ogden, J. C., Ebersole, J. P. (1981). Scale and community structure of coral reef fishes: a long-term study of a large artificial reef. Mar. Ecol. Progr. Ser. 4: 97-103

Oliver, J. S., Slattery, P. N., Hulberg, L. W., Nybakken, J. W. (1980). Relationship between wave disturbance and zonation of benthic invertebrate communities along a subtidal high-energy beach in Monterey Bay, California. Fish. Bull. U.S. $78: 437-454$

Phillips, F. E., Fleeger, J. W. (1985). Meiofauna meso-scale variability in two estuarine habitats. Estuar. cstl Shelf Sci. 21: 745-756

Richter, W., Sarnthein, M. (1977). Molluscan colonization of different sediments on submerged platforms in the western Baltic Sea. In: Keegan, B. F., Ceidigh, P. O., Boaden, P. 
J. S. (eds.) The biology of benthic organisms. Pergamon Press, Oxford, p. 531-539

Riddle, M. J. (1988). Patterns in the distribution of macrofaunal communities in coral reef sediments on the central Great Barrier Reef. Mar Ecol. Prog. Ser. 47: 281-292

Sale, P. F. (1980). The ecology of fishes on coral reefs. Oceanogr. mar. biol. A. Rev. 18: 367-421

Sale, P. F. Douglas, W. A. (1984). Temporal variability in the community structure of fish on coral patch reefs and the relation of community structure to reef structure. Ecology 65: 409-422

Salvat, B. (1972). La faune benthique du lagon de l'atoll de Reao (Tuamotu, Polynesie). Cah. Pacif. 16: 29-109

St John, J., Jones, G. P., Sale, P. F. (in press). The distribution and abundance of soft-sediment meiofauna and a predatory goby in a coral reef lagoon. Coral Reefs 8: 51-57

Suchanek, T. H., Colin, P. L. (1986). Rates and effects of bioturbation by invertebrates and fishes at Enewetak and Bikini atolls. Bull. mar. Sci. 38: 25-34

Taylor, J. D. (1971). Reef associated molluscan assemblages in the western Indian Ocean. Symp. zool. Soc. Lond. 28: 501-534

Thomassin, B. (1978). Soft-bottom communities. In: Stoddart,

This article was presented by Dr G. F. Humphrey, Sydney, Australia
D. R., Johannes, R. E. (eds.) Coral reefs: research methods. UINESCO, p. 263-298

Thomassin, B. A., Jouin, C., Renaud-Mornant, J., Richard, G.. Salvat, B. (1982). Macrofauna and meiofauna in the coral sediments on the Tiahura Reef complex, Moorea Island (French Polynesia). Tethys 10: 392-397

Thomassir, B. A., Vivier, M.-H., Vitiello, P. (1976). Distribution de la meiofaune et de la macrofaune des sables coralliens de la retenue d'eau epirecifale du grand recif de Tulear (Madagascar). J. exp. mar. Biol. Ecol. 22: $31-53$

Underwood, A. J. (1981). Techniques of analysis of variance in experimental marine biology and ecology. Oceanogr. mar. biol. A. Rev, 19: 513-605

Van Blaricom, G. R. (1982). Experimental analyses of structural regulation in a marine sand community exposed to oceanic swell. Ecol. Monogr. 52: 283-305

Whitlach, R. B. (1981). Animal-sediment relationships in intertidal marine benthic habitats: some determinants of deposit-feeding species diversity. J. exp. mar. Biol. Ecol. 53: $31-45$

Williams, B. K. (1983). Some observations on the use of discriminant analysis in ecology. Ecology 64: 1283-1291

Manuscript first received: May 31, 1989

Revised version accepted: October 17, 1989 